\title{
Kinetic properties and stability of glucose dehydrogenase from Bacillus amyloliquefaciens SB5 and its potential for cofactor regeneration
}

Thunyarat Pongtharangkul ${ }^{1 *}$, Pattra Chuekitkumchorn ${ }^{1}$, Nhuengtida Suwanampa ${ }^{1}$, Panwajee Payongsri ${ }^{1}$, Kohsuke Honda ${ }^{2}$ and Watanalai Panbangred ${ }^{1}$

\begin{abstract}
Glucose dehydrogenases (GluDH) from Bacillus species offer several advantages over other $\mathrm{NAD}(\mathrm{P}) \mathrm{H}$ regeneration systems including high stability, inexpensive substrate, thermodynamically favorable reaction and flexibility to regenerate both NADH and NADPH. In this research, characteristics of GluDH from Bacillus amyloliquefaciens SB5 (GluDHBA) was reported for the first time. Despite a highly similar amino acid sequence when comparing with GluDH from Bacillus subtilis (GluDH-BS), GluDH-BA exhibited significantly higher specific activity (4.7-fold) and stability when pH was higher than 6 . While an optimum activity of $\mathrm{GluDH}-\mathrm{BA}$ was observed at a temperature of $50{ }^{\circ} \mathrm{C}$, the enzyme was stable only up to $42^{\circ} \mathrm{C}$. GluDH-BA exhibited an extreme tolerance towards $n$-hexane and its respective alcohols. The productivity of GluDH obtained in this study ( $8.42 \mathrm{mg}$-GluDH/g-wet cells; $1035 \mathrm{U} / \mathrm{g}$-wet cells) was among the highest productivity reported for recombinant $E$. coli. With its low $K_{\mathrm{M}}$-value towards glucose $(5.5 \mathrm{mM})$ and $\mathrm{NADP}^{+}(0.05 \mathrm{mM})$, GluDH-BA was highly suitable for in vivo applications. In this work, a recombinant solvent-tolerant B. subtilis BA overexpressing GluDH-BA was developed and evaluated by coupling with B. subtilis overexpressing an enzyme P450 BM3 F87V for a whole-cell hydroxylation of $n$-hexane. Significantly higher products obtained clearly proved that $B$. subtilis BA was an effective cofactor regenerator, a valuable asset for bioproduction of value-added chemicals.
\end{abstract}

Keywords: gdh, Glucose 1-dehydrogenase, Cofactor regeneration, Bacillus amyloliquefaciens

\section{Introduction}

Bio-based chemical production has been depicted as a promising approach to a sustainable chemical manufacturing. Biocatalytic oxidoreductions hold great potential for industrial production of enentiopure chemicals and pharmaceuticals. Most oxidoreductase enzymes, however, require prohibitively expensive nicotinamide cofactors (NADH or NADPH). To date, the use of NADPH-dependent catalysts has been severely limited by an absence of efficient methods to recycling the cofactor. An efficient cofactor regeneration system is,

\footnotetext{
${ }^{*}$ Correspondence: thunyarat.pon@mahidol.ac.th

${ }^{1}$ Department of Biotechnology, Faculty of Science, Mahidol University,

Bangkok 10400, Thailand

Full list of author information is available at the end of the article
}

therefore, one of the most critical requirements prior to a commercialization of biocatalytic oxidoreductions. Thus far, biological approaches using either isolated enzyme or whole-cell biocatalyst seem to exhibit the highest potential for commercial applications (de Wildeman et al. 2007).

Glucose dehydrogenase (GluDH; EC 1.1.1.47) catalyzes the oxidation of $\beta$-D-glucose to $\beta$-D-glucono- 1,5 lactone with simultaneous reduction of the cofactor $\mathrm{NAD}(\mathrm{P})^{+}$to $\mathrm{NAD}(\mathrm{P}) \mathrm{H}$. The enzyme occurs in a variety of organisms such as Bacillus megaterium, Bacillus subtilis, Gluconobacter suboxydans, Halobacterium mediterranei, Thermoplasma acidophilum, and Sulfolobus solfataricus. GluDHs from different organisms show diverse biochemical properties (e.g. activity and

\section{Springer}


stability) and preference towards the cofactors (NAD ${ }^{+}$ and $\mathrm{NADP}^{+}$). Amino acid sequence alignment indicated that $\mathrm{NAD}(\mathrm{P})^{+}$-dependent GluDHs from the Bacillus species, belonging to the extended superfamily of shortchain dehydrogenases/reductases (SDR) (Nishiya et al. 2004), have more than $80 \%$ homology (Xu et al. 2007). GluDH from B. subtilis (GluDH-BS) has been used extensively for in vivo $\mathrm{NAD}(\mathrm{P}) \mathrm{H}$ regeneration (Zhu et al. 2006; Schewe et al. 2008; Zhang et al. 2009, 2011; Richter et al. 2010), mainly because of its dual cofactor specificity and ease of expression in a commonly used Escherichia coli hosts.

Despite its successful application in a bioproduction of epoxyhexane (Siriphongphaew et al. 2012), in this study, GluDH from Bacillus amyloliquefaciens SB5 (GluDHBA) was studied in detail in order to evaluate its full potential in biocatalysis. A GluDH-encoding gene from B. amyloliquefaciens SB5 has been cloned and expressed in both E. coli and B. subtilis. The kinetics and biochemical properties of the purified enzyme were evaluated. To our knowledge, this is the first report on characteristics of GluDH from B. amyloliquefaciens. Moreover, for an in vivo application, a recombinant $B$. subtilis 168 overexpressing GluDH-BA (referred as B. subtilis BA) was evaluated as a whole-cell cofactor regenerating biocatalyst for hydroxylation of $n$-hexane by coupling with $B$. subtilis overexpressing P450 BM3 F87V.

\section{Methods}

\section{Chemicals and media}

All chemicals used were of analytical grade and commercially available from Sigma-Aldrich (USA). Luria-Bertani (LB) and Tryptic soy broth (TSB) were used for cultivation and storage of working culture. For solid media, 1.5 \% Bacto Agar (Lab M, Lancashire, UK) was added. Ampicillin (Amp) at $50 \mu \mathrm{g} / \mu \mathrm{l}$ and tetracycline (Tet) at 20 $\mu \mathrm{g} / \mu \mathrm{l}$ were used for selection and cultivation of recombinant $E$. coli and B. subtilis, respectively.

\section{Strains, plasmids and culture conditions}

B. amyloliquefaciens SB5 was previously isolated from a petroleum contaminated soil using an enrichment technique with benzene as a screening agent. Its identity was confirmed using bioMerieux api ${ }^{\text {TM }} 20 \mathrm{E}$ and $50 \mathrm{CHB} / \mathrm{E}$ test strips (bioMerieux, Marcy L'Etoile, France) and 16s rDNA sequencing. The strain was deposited to TISTR Microbiological Resources Centre (Pathumthani, Thailand) under the accession number TISTR2086. Bacillus subtilis 168 (BGSC 1A1) was kindly provided by Bacillus Genetic Stock Center (BGSC, Columbus, OH). Recombinant B. subtilis 3C5N (pHBGA), referred as B. subtilis B-7, was developed previously by Siriphongphaew et al. (2012).

\section{Construction of recombinant plasmids for an expression of glucose 1-dehydrogenase in E. coli}

Standard procedures according to Sambrook and Russell (2001) were used for DNA manipulation of E. coli. Full length $g d h$ genes were amplified by high-fidelity PCR from genomic DNA of B. subtilis 168 and $B$. amyloliquefaciens SB5 using primers designed based on known sequences of $g d h$ from $B$. subtilis 168 (Accession No. NC000964) and B. amyloliquefacien FZB42 (Accession No. ABS72817) (Table 1; primers no. 1, 2 and 3). To facilitate the PCR amplification, the genomic DNA was digested with HindIII before being used as a template. The amplified fragments $(0.8 \mathrm{~kb})$ were retrieved after running on a $1.5 \%$ agarose gel and then cloned into pJET1.2/blunt-end cloning vector (Thermo Scientific, IL, USA), resulting in plasmids named as pJET-gdh-bs and PJET- $g d h-b a$. The nucleotide sequence of $g d h$ from B. amyloliquefaciens SB5 ( $g d h-b a)$ was determined and compared with those of other bacteria. In order to simplify the purification process, the $g d h-b a$ fragment was then amplified with primers in which nucleotides coding for a $6 \times$ His-tag were placed immediately after the start codon (Table 1; primers no. 4 and 5). The fragment was double digested with $\mathrm{NdeI}$ and $\mathrm{XhoI}$ and ligated into pET23b + (Novagen) digested with the same pair of enzymes. The plasmid pET23b-gdh-ba was introduced into $E$. coli $\mathrm{DH} 5 \alpha$ and the sequence of $g d h$ genes were confirmed by sequencing before subcloning into $E$. coli BL21(DE3).

\section{Purification of GluDH-BA}

The entire purification process was performed at $4{ }^{\circ} \mathrm{C}$. Escherichia coli BL21(DE3) harboring the plasmid pET23b-gdh- $b a$ was cultivated in an auto-induction medium (containing $0.5 \mathrm{~g} / \mathrm{L}$ glucose, $6 \mathrm{~g} / \mathrm{L}$ glycerol, $2 \mathrm{~g} / \mathrm{L}$ lactose, $10 \mathrm{~g} / \mathrm{L}$ peptone, $5 \mathrm{~g} / \mathrm{L}$ yeast extract, $5 \mathrm{~g} / \mathrm{L}$ sodium chloride, $6 \mathrm{~g} / \mathrm{L} \mathrm{Na}_{2} \mathrm{HPO}_{4}$ and $3 \mathrm{~g} / \mathrm{L} \mathrm{KH}_{2} \mathrm{PO}_{4}$ ) at $37{ }^{\circ} \mathrm{C}$, $200 \mathrm{rpm}$ for $6 \mathrm{~h}$ and then at $20^{\circ} \mathrm{C}, 200 \mathrm{rpm}$ for $14 \mathrm{~h}$. Cells were harvested, resuspended in phosphate buffer $(\mathrm{pH} 8)$ and broken with Bead beater-1 $(0.25 \mathrm{~g}$ of $1-\mathrm{mm} \phi$ glass bead per ml; 90 s per cycle at $4300 \mathrm{rpm} ; 5$ cycles; chilled on ice for $1 \mathrm{~min}$ between each cycle) (Biospec, OK, USA). After centrifugation at $11,337 \times g, 4{ }^{\circ} \mathrm{C}$ for $30 \mathrm{~min}$, the supernatant was collected and purified using PrepEase ${ }^{\circledR}$ Histidine-Tagged Protein Purification Kits - High Specificity according to the recommended protocol (usb, $\mathrm{OH}$, USA). The purified enzyme was diluted $(5 \times)$ with CitratePhosphate-Borate or CPB buffer ( $\mathrm{pH}$ 6) and then concentrated using a spin filter with MWCO of $10 \mathrm{kDa}$ prior to a storage at $-80{ }^{\circ} \mathrm{C}$. The protein concentration was determined by the Bradford assay (Bradford 1976) using bovine serum albumin as a standard. SDS-PAGE was carried out on a 4-12 \% Bis-Tris Gel (NuPAGE Novex, Thermo 
Scientific, IL, USA) at a constant current (15 mA/gel). PageRuler ${ }^{\mathrm{TM}}$ Prestained Protein Ladder (Thermo Scientific, IL, USA) was used as a molecular mass marker. After electrophoresis, the gel was stained with Coomassie brilliant blue R-250 (Laemmli 1970) and de-stained by soaking in the methanol:acetic acid solution.

\section{Construction of recombinant plasmids and expression of glucose 1-dehydrogenase in $B$. subtilis}

Bacillus subtilis 168, previously reported to exhibit an organic solvent-tolerant property (Siriphongphaew et al. 2012), was selected as a host for development of a whole-cell cofactor regenerator. The $g d h$ fragments were amplified from the plasmid pJET- $g d h-b s$ and pJET$g d h-b a$ using primers containing restriction sites for BsrGI and KpnI (Table 1; primers no. 3, 6 and 7). After a double digestion with $B s r G \mathrm{I}$ and $K p n \mathrm{I}$, the fragments were inserted into a Bacillus expression vector pHP2N. Plasmid pHP2N was constructed based on a plasmid backbone of $E$. coli-Bacillus shuttle vector pHY300PLK (TaKaRa, Shiga, Japan) with an insertion of a strong P2 promoter from a commercial expression plasmid pNCMO2 (TaKaRa, Shiga, Japan). The resulting plasmids, named as pHGBS and pHGBA, were introduced into B. subtilis 168 by electroporation using a protocol described previously (Siriphongphaew et al. 2012). Successful transformation was checked by a colony PCR as well as a restriction analysis. The recombinant $B$. subtilis 168 overexpressing GluDH-BS and GluDH-BA were referred as B. subtilis BS and B. subtilis BA, respectively.

\section{Crude enzyme preparation}

Crude enzyme extract was prepared from B. subtilis BS and $B$. subtilis BA as follow. Cells were cultivated in $\mathrm{LB}_{\text {tet }}$ at $37{ }^{\circ} \mathrm{C}, 200 \mathrm{rpm}$ for $16 \mathrm{~h}$, harvested by centrifugation at $11,337 \times g$ for $10 \mathrm{~min}$, washed twice and re-suspended in CPB buffer to an optical density $(600 \mathrm{~nm})$ of 10 . Cells were broken with Bead beater as previously described and supernatant was collected after centrifugation at $11,337 \times g$ for $10 \mathrm{~min}$.

\section{GluDH activity assay}

GluDH activity was assayed by measuring the absorbance of NAD(P)H at $340 \mathrm{~nm}$. Unless specified otherwise, the reaction was performed in $50 \mathrm{mM}$ Tris-Cl buffer $(\mathrm{pH} 8)$ with $0.5 \mathrm{mM} \mathrm{NAD}(\mathrm{P})^{+}$and $50 \mathrm{mM}$ glucose at $37^{\circ} \mathrm{C}$. The concentration $(\mathrm{U} / \mathrm{ml})$ was calculated using the millimolar extinction coefficient $\left(\varepsilon_{340}\right)$ of 6.22 . One unit $(\mathrm{U})$ of GluDH activity was defined as the formation of $1 \mu$ mole of $\mathrm{NAD}(\mathrm{P}) \mathrm{H}$ per minute and the specific activity was reported in terms of $\mathrm{U} / \mathrm{g}$-CDW as well as $\mathrm{U} / \mathrm{mg}$-protein.

\section{Effect of $\mathrm{pH}$ and temperature on activity and stability of purified GluDH-BA and intracellular GluDH-BA}

Effect of $\mathrm{pH}$ on specific activity of purified GluDH-BA was determined by measuring the activity at $37^{\circ} \mathrm{C}$ using $\mathrm{CPB}$ buffer with a $\mathrm{pH}$ range from 5 to 10 . The effect of $\mathrm{pH}$ on enzyme stability was determined from the residual activity (\%) after incubating the purified enzyme in the CPB buffer with a specified $\mathrm{pH}$ at $30{ }^{\circ} \mathrm{C}$ for $6 \mathrm{~h}$. The stability of the enzyme inside the whole-cell biocatalyst was determined in a similar manner except that the cell suspension $\left(\mathrm{OD}_{600}=10\right)$ was incubated in the specified buffer for $6 \mathrm{~h}$ before being used for preparation of crude extract. For comparison, the stability of intracellular GluDH-BA was compared with those of crude GluDHBS and crude GluDH-BA prepared from B. subtilis BS and $B$. subtilis $\mathrm{BA}$, respectively.

Effect of temperature on activity and stability of the purified GluDH-BA was evaluated using $\mathrm{CPB}(\mathrm{pH} 6)$ over the temperature range of $10-60{ }^{\circ} \mathrm{C}$. The effect of temperature on stability was determined from the residual activity after incubating the enzyme at a specified temperature for $6 \mathrm{~h}$.

\section{Effect of organic solvents on stability of GluDH-BS and GluDH-BA}

Effect of various organic solvents (DMSO, acetone, ethanol, $n$-butanol, $n$-hexane, 1-hexanol and 2-hexanol) on stability of the purified GluDH-BS and GluDH-BA were evaluated by incubating the enzyme with either 10 or

Table 1 Primers used in this study

\begin{tabular}{lll}
\hline No. & Primer & Sequence \\
\hline 1 & gdh-bs-F-BamHI & $5^{\prime}$ CCGGATCCATGTATCCGGATTTAAAAGGAA3' \\
2 & gdh-ba-F-BamHl & $5^{\prime}$ CCGGATCCATGTACACGGATTAAAAGGAA3' \\
3 & gdh-R-Kpnl & $5^{\prime}$ CTGGTACCTTATCCGCGGCCTG3' \\
4 & gdh-ba-F-Ndel-His & $5^{\prime}$ CGCCATATGCACCACCACCACCACCACTACACGGATTTAAAAGGAAAAG3' \\
5 & gdh-R-Xhol & $5^{\prime}$ CCGCTCGAGTTATCCGCGGCCTGCCTGGAATG3' \\
6 & gdh-bs-F-BsrGl & $5^{\prime}$ CCIGTACAATGTATCCGGATTTAAAAGGAA3' \\
7 & gdh-ba-F-BsrGl & $5^{\prime}$ CCIGTACAATGTACACGGATTTAAAAGGAA3' \\
\hline
\end{tabular}

Restriction sites are underlined 
$50 \%(\mathrm{v} / \mathrm{v})$ of the specified organic solvent at $30{ }^{\circ} \mathrm{C}$ for $1 \mathrm{~h}$. The GluDH activity was then assayed using CPB (pH 6) at $37{ }^{\circ} \mathrm{C}$. Relative activity (\%) was calculated based on a control in which water was added instead of the organic solvent.

\section{Steady-state kinetics}

Apparent $K_{\mathrm{M}}$ and $V_{\max }$ value of the purified GluDH-BA were determined using various substrate concentrations (10-250 $\mathrm{mM}$ of glucose) at a fixed concentration of the acceptor $\left(0.5 \mathrm{mM}\right.$ of $\mathrm{NAD}^{+}$or $\left.\mathrm{NADP}^{+}\right)$. Double reciprocal plot was used to determine $K_{\mathrm{M}}$ and $V_{\max }$ and only the concentrations that did not cause substrate inhibition were used. The initial rate was determined by linear regression as a slope of the linear plot between $\mathrm{NAD}(\mathrm{P}) \mathrm{H}$ formation and time.

\section{Application of B. subtilis BA as a whole-cell cofactor regenerator}

Bacillus subtilis BA was evaluated as a whole-cell cofactor regenerating biocatalyst for hydroxylation of $n$-hexane by coupling with $B$. subtilis $3 \mathrm{C} 5 \mathrm{~N}$ overexpressing P450 BM3 F87V (referred as B. subtilis B-7) (Fig. 1). Bacillus subtilis B-7 and B. subtilis BA were cultivated in $\mathrm{LB}_{\text {tet }}$ at $37^{\circ} \mathrm{C}, 200 \mathrm{rpm}$ for $12 \mathrm{~h}$, harvested, washed, and resuspended in a reaction buffer (100 mM KPi buffer, $\mathrm{pH}$ 7 supplemented with $110 \mathrm{mM}$ glucose) to $\mathrm{OD}_{600}$ of 25 . For permeabilized B. subtilis B-7, $1 \mathrm{ml}$ of the cell suspension was treated with $10 \mu \mathrm{l}$ of toluene for $1 \mathrm{~h}$ before being used for a bioconversion in which $0.2 \mathrm{mM} \mathrm{NADP}^{+}$was supplemented. Then, $100 \mathrm{mM}$ of $n$-hexane was added into the cell suspension $(1 \mathrm{ml})$ to start the reaction and the mixture was incubated at $30{ }^{\circ} \mathrm{C}, 200 \mathrm{rpm}$ for $3 \mathrm{~h}$. Finally, hexanols (2- and 3-hexanol) were extracted using $400 \mu \mathrm{L}$ of butyl acetate and quantified by using GC (GC2014, Shimadzu, Japan) equipped with a flame ionization detector (FID) and a DB-WAX column (30 $\mathrm{m}$ in length, $0.25 \mathrm{~mm}$ inner diameter, and $0.25 \mu \mathrm{m}$ film thickness; J
\& W Scientific, Folsom, CA, USA). Helium was used as a carrier gas at a total flow rate of $1 \mathrm{ml} / \mathrm{min}$. The sample was injected using a split mode with a split ratio of 5:1. The injector and FID detector temperature were set at 250 and $260{ }^{\circ} \mathrm{C}$, respectively. The column temperature profile was $40-160{ }^{\circ} \mathrm{C}$ at $8{ }^{\circ} \mathrm{C} / \mathrm{min}, 160-240{ }^{\circ} \mathrm{C}$ at $20{ }^{\circ} \mathrm{C} / \mathrm{min}$ and $240{ }^{\circ} \mathrm{C}$ for $5 \mathrm{~min}$. The calibration curves were constructed based on the peak areas of commercial standards prepared in Kpi buffer ( $\mathrm{pH} \mathrm{7)}$ ) and extracted using the same procedure as samples.

\section{Statistical analysis}

All experiments were performed in duplicate. Statistical analysis including ANOVA and multiple comparisons (Tukey's test) were performed using Minitab (Release 15, State College, PA, USA).

\section{Strain and amino acid sequence}

B. amyloliquefaciens SB5 has been deposited to Thailand Institute of Scientific and Technological Research or TISTR (Pathumthani, Thailand) with the accession number TISTR2086. An amino acid sequence of its gdh gene has been submitted to the GenBank nucleotide sequence database (NCBI) under an accession number JQ305165.

\section{Results}

Amino acid sequence and structural analysis of GluDH from $B$. amyloliquefaciens SB5

Interestingly, B. amyloliquefaciens SB5 exhibited a highly active $\mathrm{NAD}(\mathrm{P}) \mathrm{H}$-regenerating activity when compared with the most studied Bacillus host B. subtilis 168 and B. subtilis $3 \mathrm{C} 5 \mathrm{~N}$, our organic solvent-tolerant host previously reported (Siriphongphaew et al. 2012) (Table 2). A full-length $g d h$ gene $(786 \mathrm{bp})$ of B. amyloliquefaciens SB5 was successfully amplified from its genomic DNA using primers designed based on a $g d h$ gene of a closely related strain, B. amyloliquefaciens FZB42 (GenBank accession number ABS72817.1).
B. subtilis B-7

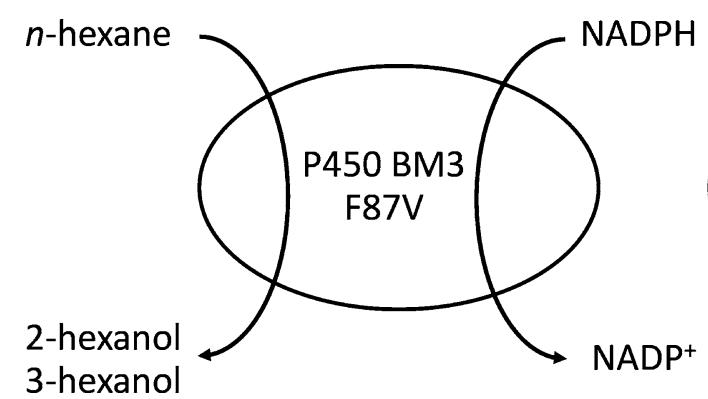

B. subtilis BA

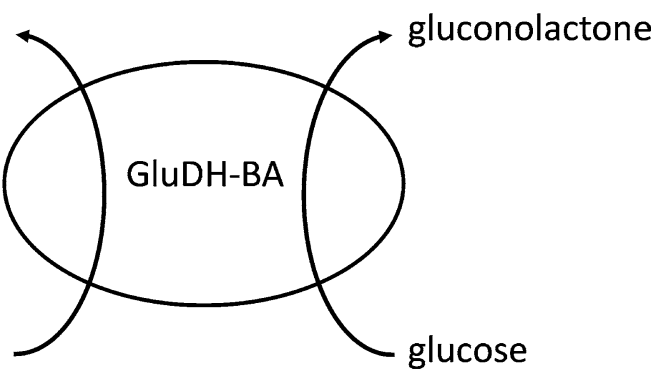

Fig. 1 Hydroxylation of $n$-hexane using a coupling whole-cell system consisting of B. subtilis B-7 and B. subtilis BA 
Table 2 GluDH activity of cell-free extracts prepared from wild-type strains and their recombinants

\begin{tabular}{lcc}
\hline Microorganism & \multicolumn{2}{c}{ GluDH activity $^{\mathbf{a}}$} \\
\cline { 2 - 3 } & $\mathbf{U} / \mathbf{g}$-CDW & U/mg-total protein \\
\hline B. subtilis 168 & $0.99 \pm 0.44$ & $0.008 \pm 0.001$ \\
B. subtilis 3C5N & $0.22 \pm 0.05$ & $0.002 \pm 0.000$ \\
B. amyloliquefaciens SB5 & $15.8 \pm 1.90$ & $0.166 \pm 0.085$ \\
B. subtilis B-7 & $0.02 \pm 0.02$ & $0.0002 \pm 0.0002$ \\
B. subtilis BSc & $6.84 \pm 0.59$ & $0.020 \pm 0.003$ \\
B. subtilis BA & $1601 \pm 146$ & $6.24 \pm 0.39$ \\
\hline
\end{tabular}

a The activity was determined using Tris- $\mathrm{Cl}(\mathrm{pH} 8)$ at $37^{\circ} \mathrm{C}$

b B. subtilis B-7 was a recombinant $B$. subtilis $3 \mathrm{C} 5 \mathrm{~N}$ overexpressing $\mathrm{P} 450 \mathrm{BM} 3$ F87V (Siriphongphaew et al. 2012)

c $B$. subtilis BS was a recombinant B. subtilis 168 overexpressing GluDH-BS from itself

d B. subtilis BA was a recombinant B. subtilis 168 overexpressing GluDH-BA from B. amyloliquefaciens SB5

Alignment of the deduced amino acid sequence of GluDH-BA (261 aa) with its bacterial counterparts showed highest similarity with GluDH from $B$. amyloliquefaciens FZB42 (99 \%) and high similarity of 89 \% with GluDH from B. subtilis 168 (UniProtKB entry number P12310). The catalytic tetrad, Asn116-Ser145Tyr158-Lys162, conserved among other GluDHs was also present (Fig. 2). Both GluDHs, GluDH-BS from $B$. subtilis 168 and GluDH-BA from B. amyloliquefaciens SB5, showed high level of similarity (82 and $83 \%$, respectively) toward the GluDH IV (P39485), a GluDH with a known crystal structure (Nishioka et al. 2012). With this high level of sequence similarity, proteins would have the same folding, architecture and overall quaternary structure even if GluDH-BS and GluDH-BA exhibited different kinetic properties as illustrated in Table 3.

All GluDHs compared in Fig. 2 belong to the extended superfamily of short-chain dehydrogenases/reductases (SDR) with an expected size of approximately $28 \mathrm{kDa}$. The crystal structure of GluDH IV (referred as GluDH-BM in this study) from Bacillus megaterium (PDB ID 3AY6) was illustrated in Fig. 3. Crystal structure analysis allowed us to identify amino acid residues that constitute the active site channel, defined as any amino acids located 4 A from glucose and $\mathrm{NAD}^{+}$. Twenty-nine amino acids that are different between GluDH-BA and GluDH-BS are shown as magenta stick (Fig. 3). Together with sequence alignment in Fig. 2, it was clear that majority of the differences between these two GluDHs were outside of the active site channel except only an amino acid at position 95. The fact that the most variable region was at the nucleotide binding domain may contributes to an extremely low $K_{\mathrm{M}}$ towards $\mathrm{NADP}^{+}$observed in GluDH-BA.
From structural analysis, most of the variable amino acids are located on rather highly flexible regions (Fig. 3b). Interestingly, there were cases where a mutation at the flexible regions improved the thermostability of an enzyme (Reetz et al. 2006). In order to evaluate the effect of amino acid variation between GluDH-BS and GluDHBA on their activity and stability, we compared these variations with previous mutagenesis studies. Only P45A mutation has been previously reported to enhance activity and stability of GluDH-BS, even though the location of this amino acid is further away from the active site and subunit interface (Vázquez-Figueroa et al. 2007). Also, a single mutation of amino acids outside the active site channel (i.e. F155Y and E170 K) in GluDH-BS has been shown to affect both activity and stability significantly (Vázquez-Figueroa et al., 2007). From these evidences, it is highly likely that the differences in the sequences, even though at amino acids on the surface or remote from the catalytic center, can lead to the activity and thermostability alteration. To further our understanding of the structure-function relationship, mutational analysis of other positions is now in progress.

\section{Expression and purification of GluDH-BA}

To simplify the enzyme purification, the recombinant GluDH-BA (with 6x His-tag at the N-terminal) was expressed in E. coli BL21(DE3). Based on the activity of the purified enzyme (123 U/mg-protein), GluDH-BA contributed to approximately $31 \%$ of total intracellular proteins and the purified GluDH-BA could be obtained from the crude extract ( $38.4 \mathrm{U} / \mathrm{mg}$-protein) with high yield (35\%) and purity (Fig. 4). The observed size from SDS-PAGE was, however, larger than the expected size of GluDH-BA ( $28 \mathrm{kDa}$ ) possibly as a result of the $6 \mathrm{x}$ Histag as well as the fact that 'gel shifting' phenomenon, in which the migration on SDS-PAGE does not correlate with formula molecular weight, was affected by tertiary structure of the migrated protein (Rath et al. 2009). Also, GlcDH-BS (28.1 kDa) was previously reported to appear as a band of approximately $33 \mathrm{kDa}$ by Wang et al. (2013). It should be noted that the productivity of GluDH obtained in this study (8.42 mg-GluDH/g-wet cells; $1035 \mathrm{U} / \mathrm{g}$-wet cells) is among the highest productivity reported for GluDH produced by recombinant $E$. coli (1000-1300 U/g-wet cells; Xu et al. 2007). The purified GluDH-BA was stable for at least 4 months when stored at $-80^{\circ} \mathrm{C}$ in CPB buffer (pH 6) (data not shown).

\section{Effect of pH on the activity and stability of GluDH-BA}

Despite a widespread use of Tris-Cl buffer ( $\mathrm{pH} 7.2-9.0)$ and potassium phosphate buffer $(\mathrm{pH}$ 5.0-8.0) for $\mathrm{GluDH}$ activity assay (Fujita et al. 1977; Boontim et al. 2004; 


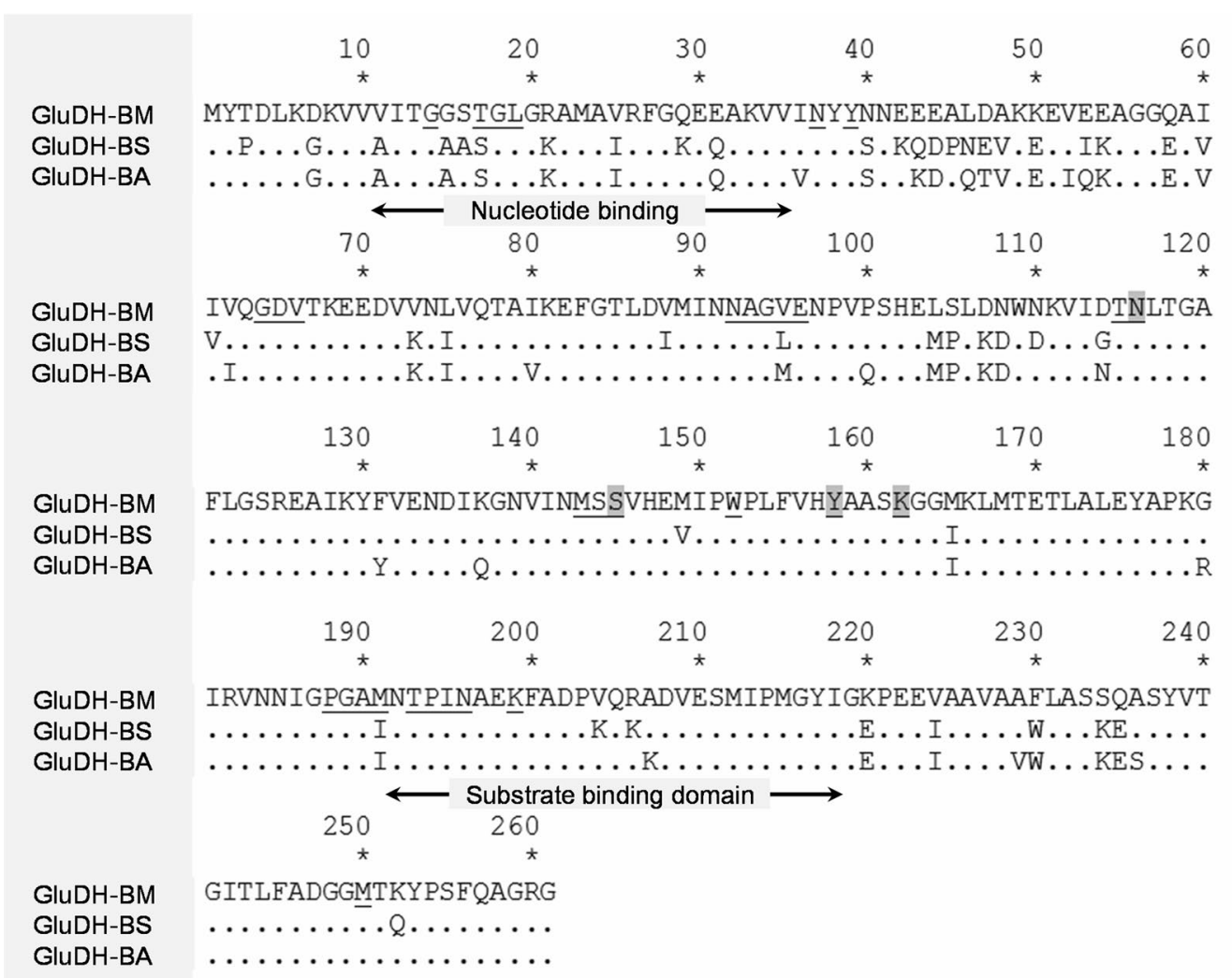

Fig. 2 Amino acid sequence alignment of GluDH-BA (JQ305165) from B. amyloliquefaciens SB5 with GluDH-BM (P39485) from B. megaterium and GluDH-BS (P12310) from B. subtilis 168. Amino acids located $4 \AA$ away from glucose and NAD ${ }^{+}$were defined as an active site channel and presented as underlined alphabets. Nucleotide binding site (amino acid 11-35), the catalytic tetrad (amino acid 116, 145, 158, and 162; highlighted in grey) and the amino acids involving in substrate binding (amino acid 192-218) are indicated in the figure

Table 3 Kinetic constants of purified GluDH from B. amyloliquefaciens SB5 comparing to those reported in the literature

\begin{tabular}{|c|c|c|c|c|c|c|c|}
\hline \multirow[t]{2}{*}{ Microorganism } & \multicolumn{3}{|c|}{$K_{\mathrm{M}}$ value $(\mathrm{mM})$} & \multirow{2}{*}{$\begin{array}{l}\text { Turnover } \\
\text { number }(1 / s)^{a}\end{array}$} & \multirow{2}{*}{$\begin{array}{l}\text { Specific activity } \\
\text { (U/mg-protein) }\end{array}$} & \multirow{2}{*}{$\begin{array}{l}\text { Optimal } \\
\text { pH }\end{array}$} & \multirow[t]{2}{*}{ References } \\
\hline & $\mathrm{NAD}^{+}$ & NADP $^{+}$ & $\beta-D-g l u c o s e^{a}$ & & & & \\
\hline Bacillus subtilis & 0.23 & 0.26 & 42.9 & n.a. ${ }^{c}$ & 26 & 9 & Fujita et al. (1977) \\
\hline $\begin{array}{l}\text { Gluconobacter } \\
\text { suboxydans }\end{array}$ & n.d. ${ }^{b}$ & 0.01 & 5 & n.a. ${ }^{c}$ & 140 & 6 & Adachi et al. (1980) \\
\hline Sulfolobus solfataricus & 1.2 & 0.03 & 0.44 & 48 & 437 & 8 & Giardina et al. (1986) \\
\hline Bacillus megaterium & 0.37 & 0.03 & 11 & 260 & n.a. ${ }^{c}$ & 6.5 & $\begin{array}{l}\text { Yamamoto et al. } \\
\text { (1990) }\end{array}$ \\
\hline $\begin{array}{l}\text { Lysinibacillus sphaericus } \\
\text { G10 }\end{array}$ & 0.09 & 0.07 & 5.1 & 93 & 205 & 9.5 & Ding et al. (2011) \\
\hline $\begin{array}{l}\text { Bacillus amyloliquefa- } \\
\text { ciens SB5 }\end{array}$ & $0.25 \pm 0.03$ & $0.05 \pm 0.004$ & $5.5 \pm 0.28$ & $70 \pm 0.3$ & $123 \pm 0.5$ & 10 & This study \\
\hline
\end{tabular}

All kinetic parameters of GluDH-BA are presented as Avg \pm SD

a With NADP ${ }^{+}$

b No activity with $\mathrm{NAD}^{+}$

c Data not available

Weckbecker and Hummel 2005), in this research, buffers with a wider $\mathrm{pH}$ range such as Britton-Robinson buffer $(\mathrm{pH}$ 2.6-11.8) and Citrate-Phosphate-Borate or CPB buffer ( $\mathrm{pH}$ 2.0-12.0) were tested and compared with a commonly used Tris-Cl in order to eliminate the effect of buffer types in a study on the effect of $\mathrm{pH}$. All three 


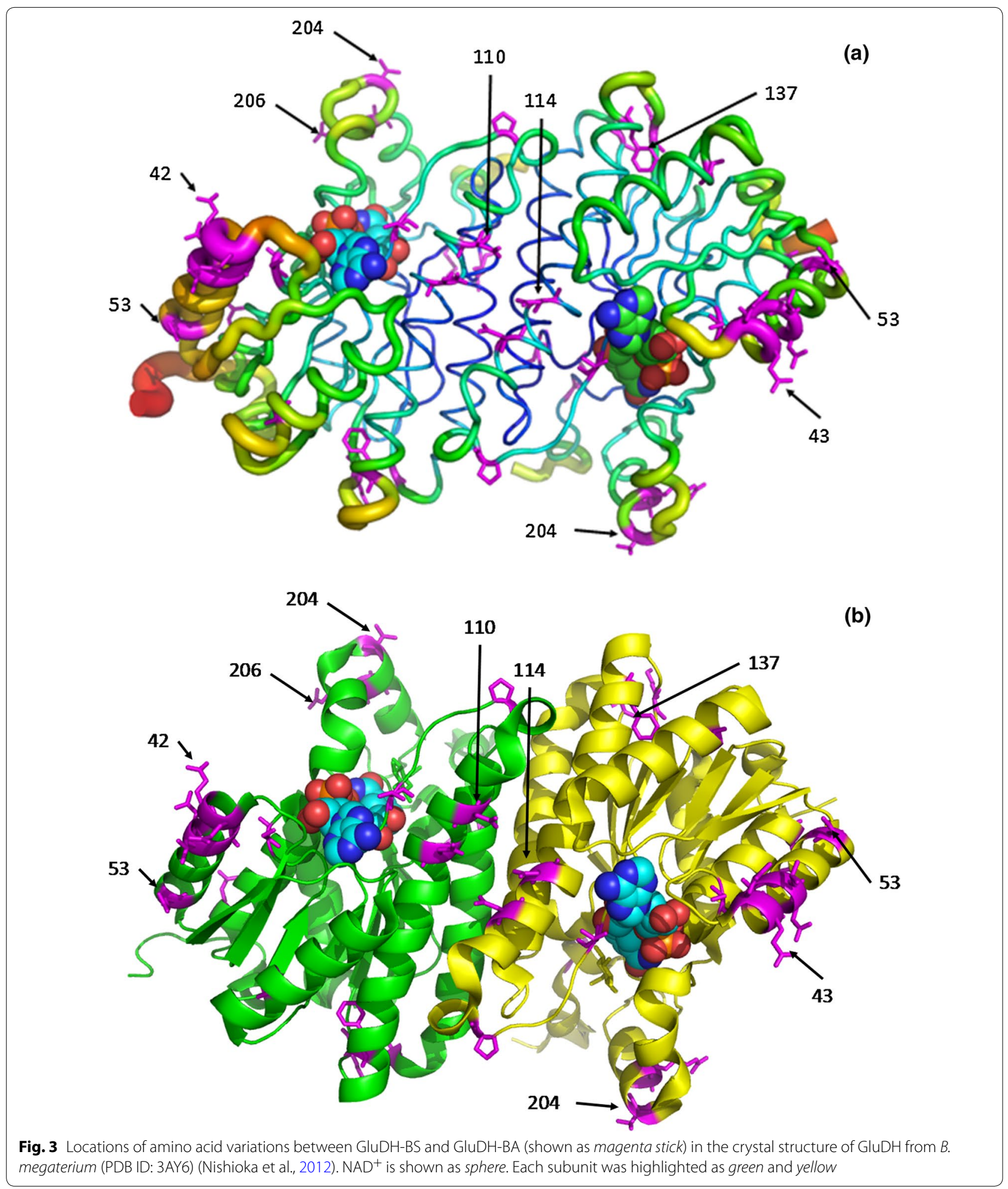

buffers were evaluated at $\mathrm{pH}$ 8, an optimum $\mathrm{pH}$ generally reported for GluDH activity assay, using GluDH-BA. While Britton-Robinson buffer resulted in a significantly lower GluDH activity (58 \% of that observed in Tris-Cl buffer), CPB buffer was found to be comparable to Tris$\mathrm{Cl}$ (not significantly different at $\alpha=0.05$ ) and therefore 


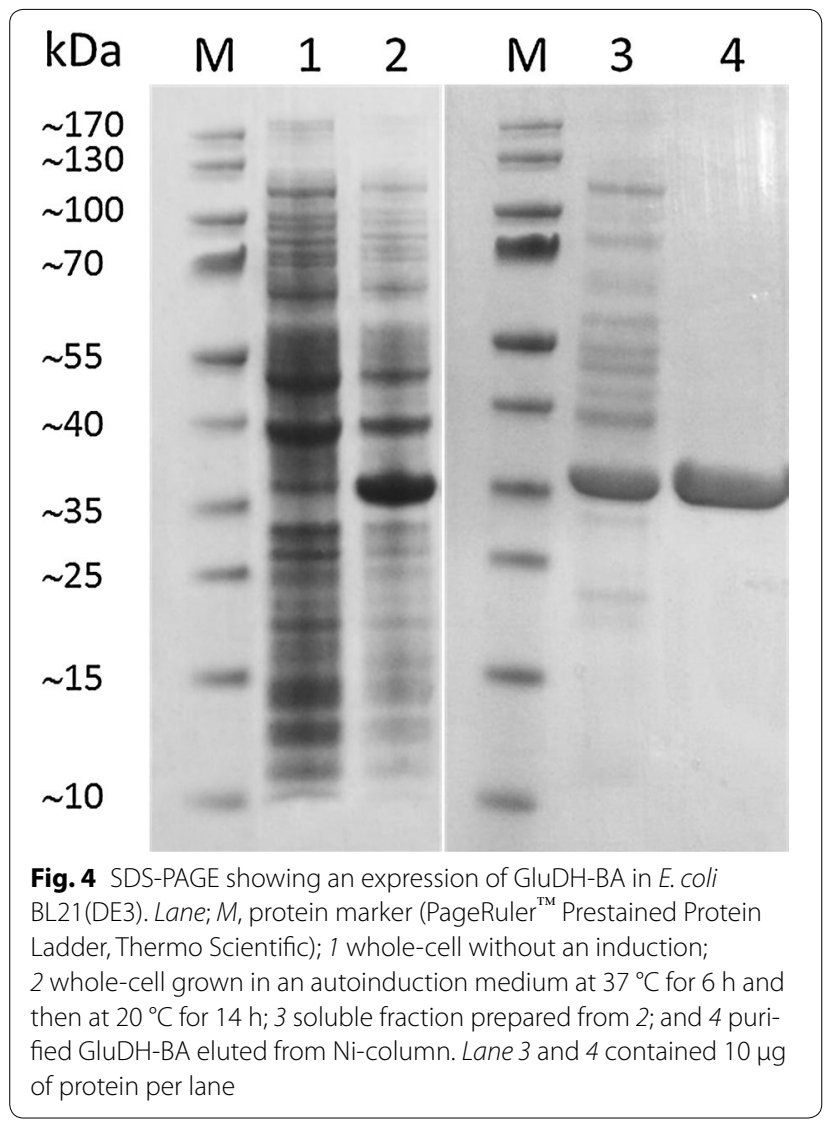

was suitable for a study on the effect of $\mathrm{pH}$. Moreover, as Tris- $\mathrm{Cl}$ was reported to interfere with the Bradford dye used for protein assay (Stoll and Blanchard 1990), CРB was used throughout the rest of this study.

The optimum $\mathrm{pH}$ for purified GluDH-BA was determined by measuring the activity at $37{ }^{\circ} \mathrm{C}$ using $\mathrm{CPB}$ buffer over the $\mathrm{pH}$ range of 5-10. As a result, the optimal $\mathrm{pH}$ of the purified GluDH-BA was observed at $\mathrm{pH} 10$ (Fig. 5), similar to that of an alkali-resistant GluDH from L. sphaericus G10 (Ding et al. 2011) but higher than $\mathrm{pH}$ 8 generally reported for GluDHs from B. subtilis (Fujita et al. 1977; Hilt et al. 1991; Weckbecker and Hummel 2005) and B. thuringiensis (Boontim et al. 2004). In this study, effect of $\mathrm{pH}$ on stability was evaluated by incubating the enzyme at a specified $\mathrm{pH}\left(30^{\circ} \mathrm{C}\right.$ for $\left.6 \mathrm{~h}\right)$ prior to an activity assay at $37{ }^{\circ} \mathrm{C}$. Stability is presented as a percentage of remaining specific activity after 6 h (Fig. 6). GluDHs from Bacillus species were generally unstable at a pH higher than 8 (Mitamura et al. 1989; Hilt et al. 1991; Nagao et al. 1992; Boontim et al. 2004) as a result of repulsion of the acidic amino acids located at the subunit-subunit interface (Nagao et al. 1989). Similar to other GluDHs from Bacillus species, purified GluDH-BA was highly stable in acidic condition (pH 5-6) but was completely inactivated at $\mathrm{pH} \geq 8$.

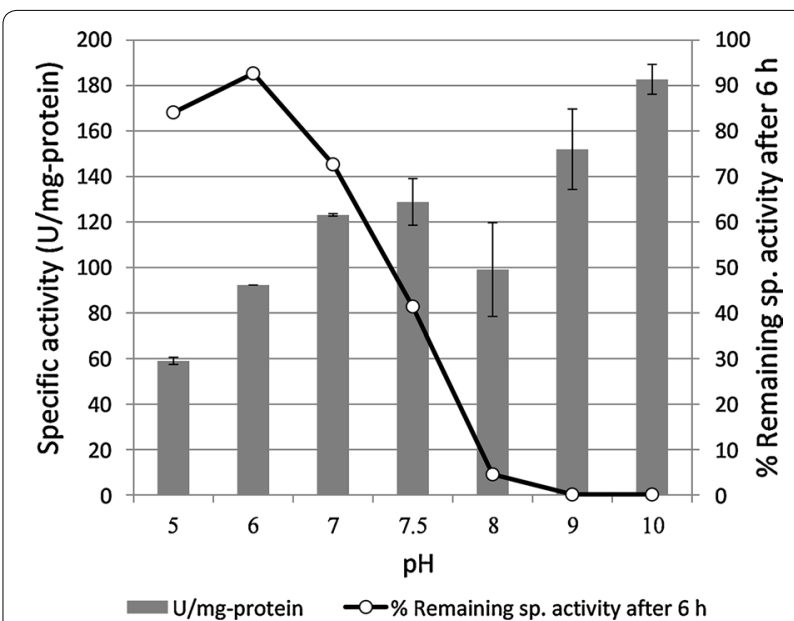

Fig. 5 Effect of $\mathrm{pH}$ on specific activity and stability of purified GluDHBA. The activity was assayed at $37^{\circ} \mathrm{C}$ using CPB buffer with a specified $\mathrm{pH}$. Vertical bars show the standard deviation of the mean based on two independent replicates. Stability is presented as \% remaining specific activity after incubating in CBP buffer with a specified $\mathrm{pH}$ at $30^{\circ} \mathrm{C}$ for $6 \mathrm{~h}$

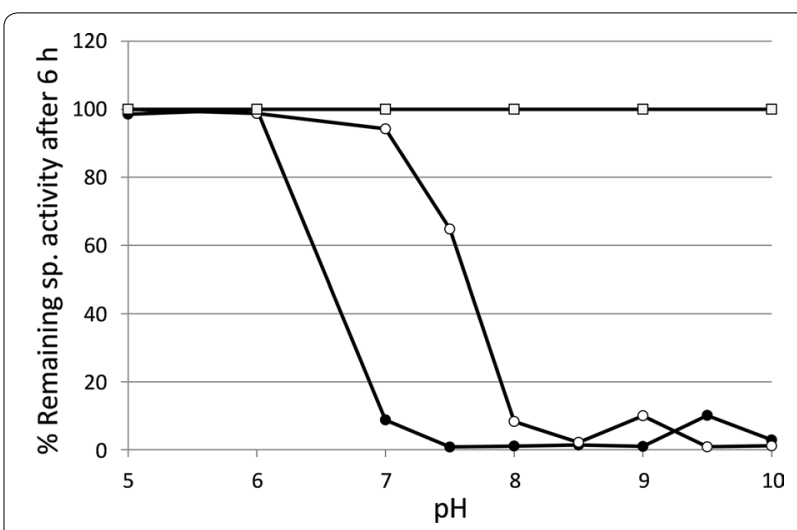

Fig. 6 Influence of pH on stability of crude GluDH-BS (closed circle) and GluDH-BA (open circle) when using NADP ${ }^{+}$as a cofactor. The activity was determined using $\mathrm{CPB}$ with a specified $\mathrm{pH}$ at $37^{\circ} \mathrm{C}$ after $6 \mathrm{~h}$ of incubation at $30^{\circ} \mathrm{C}$. Stability of in vivo GluDH-BA inside the whole-cell B. subtilis BA (open square) was determined from the cell free extract prepared after the whole-cell biocatalyst was exposed to $\mathrm{CPB}$ with a specified $\mathrm{pH}$ at $30^{\circ} \mathrm{C}$ for $6 \mathrm{~h}$. Relative activity (\%) was calculated based on the maximum activity observed at $\mathrm{pH} 5$

It should be noted that, in this study, an unusually long test period of $6 \mathrm{~h}$ was employed instead of a commonly used period of $0.5-1 \mathrm{~h}$, mainly because the bioconversion in which the enzyme will be applied are generally conducted for a long period (e.g. 3-24 h). Therefore, the conclusion drawn from this study may not agree well with that reported in a study using a shorter incubation period. For example, while GluDH from B. subtilis was previously reported to withstand up to $\mathrm{pH} 8$ with a test 
period of 20 min (Fujita et al. 1977), the crude GluDHBS (prepared from a recombinant B. subtilis BS) tested in this study was stable only up to $\mathrm{pH} 6$ when the test period of $6 \mathrm{~h}$ was used (Fig. 6). This hypothesis was confirmed when the activity of crude GluDH-BS was monitored over time at $\mathrm{pH} 8$ (Table 4). The specific activity observed decreased significantly after $30 \mathrm{~min}$ of incubation at $\mathrm{pH}$ 8. Crude GluDH-BA (prepared from a recombinant $B$. subtilis $\mathrm{BA}$ ), on the other hand, could withstand up to $\mathrm{pH}$ 7.5 (Fig. 6), similar to the purified GluDH-BA described previously (Fig. 5). Therefore, in order to obtain useful information for practical applications, the test period used for evaluation of enzyme stability should be prolonged ( $\geq 1 \mathrm{~h}$ ).

For bioconversion of toxic chemicals, tolerance of the genetically engineered host towards such chemicals was highly critical (Schewe et al. 2008; Siriphongphaew et al. 2012). When compared with E. coli DH5 $\alpha, B$. subtilis 168 exhibited significantly higher tolerance towards toxic chemicals (Siriphongphaew et al. 2012) and therefore was selected for development of a whole-cell cofactor regenerator in this study. To investigate the effect of extracellular $\mathrm{pH}$ on the stability of intracellular GluDH-BA, cells of a recombinant $B$. subtilis $\mathrm{BA}$ were incubated in $\mathrm{CPB}$ with a specified $\mathrm{pH}$ for $6 \mathrm{~h}$ and the specific activity of their cell-free extracts were then compared with that of a control (a cell-free extract prepared from the cells without an exposure). As expected, the specific GluDH activity remained unchanged regardless of the extracellular $\mathrm{pH}$ that the cells were exposed to (Fig. 6).

\section{Effect of temperature on the activity and stability of GluDH-BA}

Similar to other GluDHs reported for Bacillus species, purified GluDH-BA exhibited maximum activity at $50{ }^{\circ} \mathrm{C}$ but was found to be unstable at this temperature (Fig. 7). Surprisingly, a relatively high specific activity (80 \%) could still be observed at $60{ }^{\circ} \mathrm{C}$ where most Bacillus

$\begin{aligned} & \text { Table } 4 \% \text { Relative in specific activity of crude GluDH- } \\
& \left.\text { BS determined after incubation in CPB (pH } 8, \mathbf{3 0}^{\circ} \mathbf{C}\right) \text { for a } \\
& \text { specified period }\end{aligned}$
\begin{tabular}{ll} 
Time of exposure (h) & $\begin{array}{l}\text { \% Relative of specific } \\
\text { activity }^{\mathbf{A}}\end{array}$ \\
\hline 0 & $100 \pm 0^{\mathrm{a}}$ \\
0.5 & $73.8 \pm 14.9^{\mathrm{ab}}$ \\
1 & $41.2 \pm 15.5^{\mathrm{b}}$ \\
3 & $1.3 \pm 0.6^{\mathrm{c}}$ \\
6 & $0 \pm 0^{\mathrm{c}}$ \\
\hline
\end{tabular}

Different superscripts indicate a significant difference between treatments at $95 \%$ confidence level ( $p$ value $\leq 0.05$ )

A The GluDH activity was determined at $37^{\circ} \mathrm{C}$

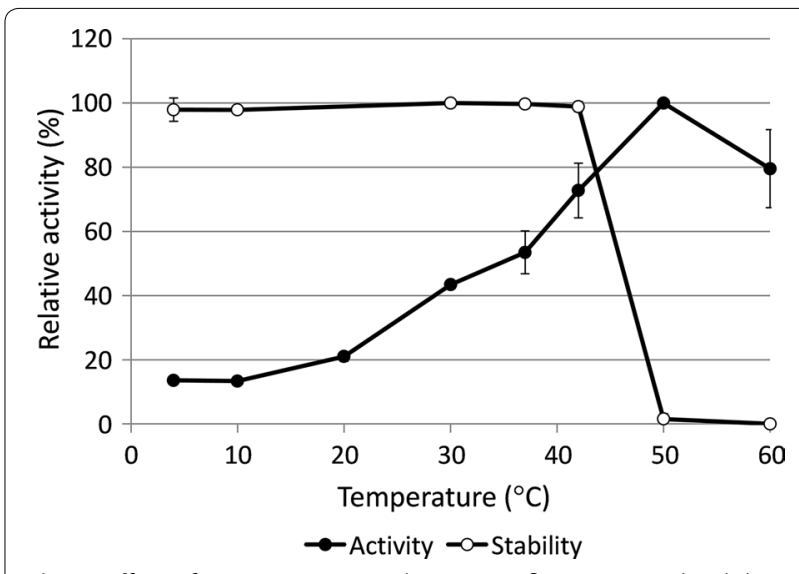

Fig. 7 Effect of temperature on relative specific activity and stability of purified GluDH-BA. The activity was determined using CPB ( $\mathrm{pH} 7$ 7) with at $\mathrm{NADP}^{+}$as a cofactor $37^{\circ} \mathrm{C}$. For stability, the remaining activity was determined after $6 \mathrm{~h}$ of incubation at a specified temperature

GluDHs exhibited almost no activity (Yamamoto et al. 1990; Nagao et al. 1992; Boontim et al. 2004).

\section{Effect of organic solvents on the stability of GluDH-BS and GluDH-BA}

According to the obtained result, purified GluDH-BA exhibited higher stability towards organic solvents than GluDH-BS, especially in the case of 1- and 2-hexanol (Table 5). Both GluDHs could tolerate high concentration of $n$-hexane, despite the fact that $50 \%(\mathrm{v} / \mathrm{v}) n$-hexane has been reported to completely eliminate the activity of an organic solvent-tolerant GluDH-Ls from Lysinibacillus sphaericus G10 after a 1-h exposure (Ding et al. 2011). The fact that GluDH-BA could withstand a high

Table 5 Stability of purified GICDH-BS and GICDH-BA in various organic solvents

\begin{tabular}{|c|c|c|c|c|c|}
\hline \multirow[t]{3}{*}{ Solvents } & \multirow[t]{3}{*}{$\log \mathrm{Po} / w$} & \multicolumn{4}{|c|}{$\%$ Relative activity ${ }^{a}$} \\
\hline & & \multicolumn{2}{|c|}{ GluDH-BS } & \multicolumn{2}{|c|}{ GluDH-BA } \\
\hline & & $10 \% \mathrm{v} / \mathrm{v}$ & $50 \% \mathrm{v} / \mathrm{v}$ & $10 \% \mathrm{v} / \mathrm{v}$ & $50 \% \mathrm{v} / \mathrm{v}$ \\
\hline DMSO & -1.4 & $87 \pm 3$ & $98 \pm 3$ & $100 \pm 0$ & $99 \pm 1$ \\
\hline Acetone & -0.2 & $80 \pm 2$ & $1 \pm 1$ & $99 \pm 1$ & $1 \pm 1$ \\
\hline Ethanol & -0.2 & $86 \pm 3$ & $1 \pm 1$ & $100 \pm 1$ & $19 \pm 16$ \\
\hline n-Butanol & 0.9 & $0 \pm 0.5$ & $0 \pm 0$ & $2 \pm 0$ & $1 \pm 1$ \\
\hline n-Hexane & 3.8 & $89 \pm 0$ & $99 \pm 1$ & $100 \pm 0$ & $100 \pm 0$ \\
\hline 1-Hexanol & 1.8 & $56 \pm 10$ & n.a. & $94 \pm 0$ & n.a. \\
\hline 2-Hexanol & 1.8 & $68 \pm 4$ & $69 \pm 1$ & $95 \pm 1$ & $93 \pm 2$ \\
\hline
\end{tabular}

The relative activity was calculated based on an activity of a control without organic solvent (water was added instead)

n.a. data not available

${ }^{a}$ The activity was determined using $\mathrm{CPB}(\mathrm{pH} 6)$ at $37^{\circ} \mathrm{C}$ after an exposure with a specified organic solvent at $30^{\circ} \mathrm{C}$ for $1 \mathrm{~h}$ 
concentration of $n$-hexane and its respective alcohols makes GluDH-BA a good candidate for cofactor regeneration in a hydroxylation of $n$-hexane.

\section{Kinetic constants}

Unlike GluDH-BS which equally preferred $\mathrm{NAD}^{+}$and $\mathrm{NADP}^{+}$as a cofactor, a purified GluDH-BA exhibited higher preference towards $\mathrm{NADP}^{+}$(Table 3), similar to GluDHI, GluDHII and GluDHIWG3 from B. megaterium (Mitamura et al. 1989; Yamamoto et al. 1990). In comparison with GluDH-BS (42.9 mM), a significantly lower $K_{\mathrm{M}}$-value towards glucose $(5.5 \mathrm{mM})$ was observed for GluDH-BA, suggesting its ability to immediately react with a small amount of glucose present in vivo. Faster $\mathrm{NAD}(\mathrm{P}) \mathrm{H}$ regeneration can be achieved at lower glucose concentration for the same amount of GluDH. Therefore, a high expression level may not be required, making GluDH-BA suitable for enzymatic cascading. Moreover, for an in vivo application in a whole-cell biocatalyst, an enzyme with low $K_{\mathrm{M}}$ for $\mathrm{NAD}(\mathrm{P})^{+}$would be most appropriate due to the low $\mathrm{NAD}(\mathrm{P})^{+}$concentration within the cell. Nonetheless, the reaction rate would depend on the turnover number of the enzyme. For this reason, GluDH from Sulfolobus solfataricus, despite having a low $K_{\mathrm{M}}$ for $\mathrm{NAD}(\mathrm{P})^{+}$, is probably not suitable for in vivo applications due to its low turnover number (Table 3).

For applications in a form of crude lysate and purified enzyme, an enzyme with high $K_{\mathrm{M}}$ (possibly for glucose but not necessary for $\mathrm{NAD}^{+}$) and high $\mathrm{k}_{\text {cat }}$ would be most preferable. Such kinetic properties would allow for an operation under high substrate concentration (glucose) and therefore fast reaction rate (dictated by the $\mathrm{k}_{\mathrm{cat}}$ ) could be obtained. GluDH with low $K_{\mathrm{M}}$ towards glucose, including GluDH from S. solfataricus, is more likely to suffer from glucose inhibition than other GluDHs. Nonetheless, for industrial and synthesis purposes, kinetic parameters alone should not be used to identify which enzyme is suitable for catalysis. Stabilities and inhibitions should also be considered. Since GluDHs are widely used as cofactor regeneration enzyme, it would be useful to have a wide range of GluDHs to select from. This is because certain variants may be inhibited or incapable in a certain $\mathrm{NAD}(\mathrm{P}) \mathrm{H}$-consuming reaction.

\section{Application as a whole-cell cofactor regenerator for hydroxylation of $n$-hexane}

In a recombinant $B$. subtilis $\mathrm{BA}$, GluDH-BA was expressed at a high level (6.24 U/mg-total protein) comparable to the GluDH activity obtained in E. coli when using the pET system $(7.18 \mathrm{U} / \mathrm{mg}$-total protein; Richter et al. 2010) or that expressed in B. subtilis under a constitutive strong promoter P43 (4.9 U/mg-total protein; Zhu et al. 2006). In this study, B. subtilis BA was evaluated as a whole-cell cofactor regenerator in a coupling whole-cell system for hydroxylation of $n$-hexane.

Coupling whole-cell system, first demonstrated by Zhang et al. (2009), uses two types of permeabilized biocatalysts expressing different enzymes, one for production of desired product and another for regeneration of required cofactor. Each reaction occurs in a separate host cell while the cofactors migrate between the two permeabilized cells. Although $n$-hexane is a small molecule that does not require cell permeabilization, it was chosen as our model substrate so that we can also evaluate the system with non-permeabilized biocatalyst as well. When coupling with a recombinant $B$. subtilis $3 \mathrm{C} 5 \mathrm{~N}$ (pHP2NB) expressing P450 BM3 F87V (referred as B. subtilis B-7), $B$. subtilis $\mathrm{BA}$ enhanced the production of 2- and 3-hexanol significantly (Fig. 8). The fact that B. subtilis BA enhanced the bioconversion even when both biocatalysts were not permeabilized suggested that glucose and $\operatorname{NADP}(\mathrm{H})$ could already gain access into the cells. Nonetheless, a small amount of hexane used as a reaction substrate might play a part in membrane permeabilization and therefore could not be ruled out.

Permeabilization by a toluene treatment (at $1 \% \mathrm{v} / \mathrm{v}$ ) was frequently employed in bioconversion to guarantee access of substrate and cofactor into the cells (Cánovas et al. 2005; Zhang et al. 2009). Unfortunately, toluene treatment resulted in an absolute loss of indigenous cofactors inside the cells and extracellular

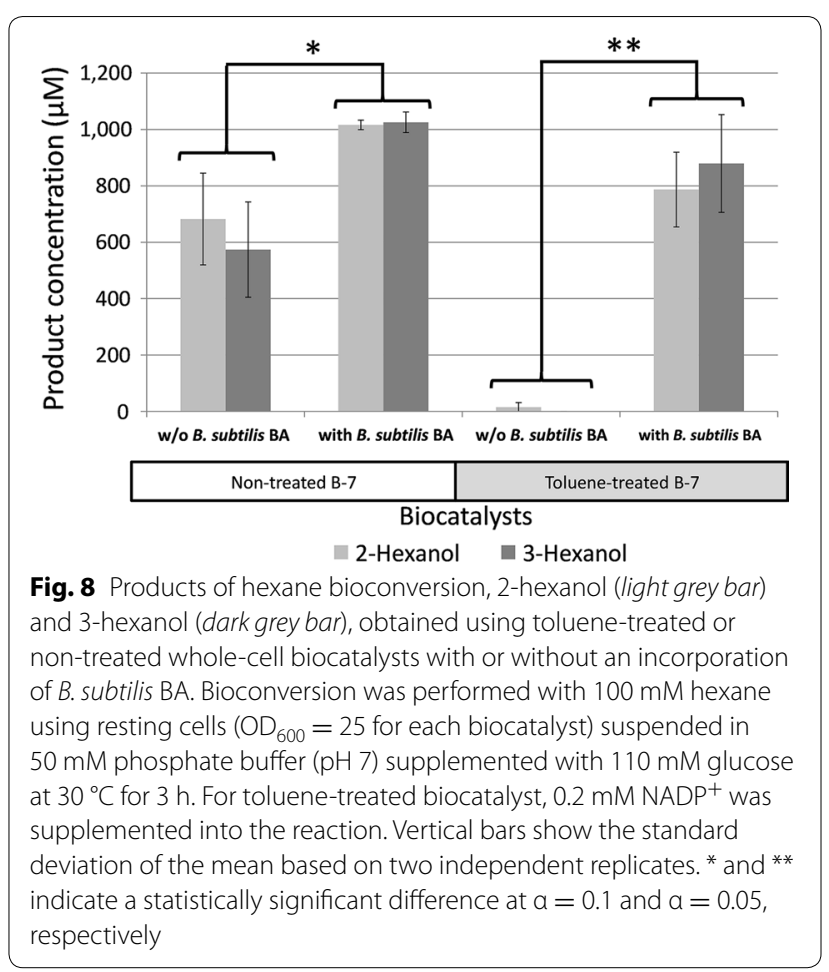


supplementation of $\mathrm{NAD}(\mathrm{P})^{+}$was necessary. Permeabilized B. subtilis B-7 failed to catalyze the hexane hydroxylation even when $0.2 \mathrm{mM} \mathrm{NADP}{ }^{+}$was supplemented extracellularly, agreeing with an extremely low GluDH activity observed previously (Table 2). Interestingly, an incorporation of a non-permeabilized whole-cell B. subtilis BA could effectively restore the bioconversion (Fig. 8).

\section{Discussions}

In this study, NAD(P)-dependent GluDH from $B$. amyloliquefaciens SB5 (GluDH-BA) has been successfully cloned and expressed in both E. coli and B. subtilis. Several strains of $B$. amyloliquefaciens have been widely regarded as a member of 'plant growth promoting rhizobacteria' or PGPR (Idriss et al. 2007). The mechanisms by which PGPR can exert a positive effect on plant growth include the solubilization of insoluble inorganic phosphate compounds (such as tricalcium phosphate and hydroxyapatite) via an action of organic acids synthesized by them. Considering the fact that gluconic acid (formed via an action of glucose dehydrogenase) was reported to be the most common agent for mineral phosphate solubilization, it was not surprising that B. amyloliquefaciens with a high level of GluDH activity has been identified as one of the most powerful inorganic phosphate solubilizers (Rodriguez and Fraga 1999). High level of GluDH activity observed in B. amyloliquefaciens SB5 (Table 2) agreed well with those findings and the phosphate solubilizing property of B. amyloliquefaciens SB5 is now being investigated in detail.

Comparing to GluDHs reported from genus other than Bacillus, the specific activity of the purified GluDH-BA (123 U/mg-protein) was comparable to that reported for G. suboxydans (Adachi et al. 1980), but lower than that of L. sphaericus G10 (Ding et al. 2011) and S. solfataricus (Giardina et al. 1986) (Table 3). Nonetheless, it should be noted that a specific activity value highly depends on several factors (i.e. buffer, $\mathrm{pH}$ and substrate concentration) and therefore may not be a good parameter for comparison. Despite a highly similar sequence with GluDH-BS, GluDH-BA exhibited significantly higher specific activity (4.7-fold) and stability when $\mathrm{pH}$ was higher than 6. GluDH-BA also exhibited higher tolerance towards organic solvents, especially hexanols.

Amino acid sequence alignment and structural analysis of both GluDHs revealed several novel potential amino acid positions [e.g. position 16 in the region of $\operatorname{NAD}(\mathrm{P})^{+}$-binding motif and position 95 in the active site channel] for further improvement of the enzyme activity and stability via site-directed mutagenesis. The 3D structure of GluDH IV from B. megaterium (Nishioka et al. 2012) revealed that amino acid position 16 was a part of the outer layer of the active site channel located at least $16 \AA$ away from the reactive center. The difference in size and chemical properties of an amino acid at this position may account for the difference in enzyme activity and stability. Despite the fact that a single mutation of amino acids outside the active site channel in GluDH-BS affected both activity and stability significantly (Vázquez-Figueroa et al. 2007), similar phenomenon can be observed as a result of accumulated mutations at scattered locations as well (e.g. an enzymesurface mutant Q42E, P45A and N46A in B. subtilis; Vázquez-Figueroa et al. 2008).

High specific activity as well as low $K_{\mathrm{M}}$-value towards glucose and NADP ${ }^{+}$of GluDH-BA suggested its potential for in vivo applications. While the high specific activity allows for an efficient cofactor recycling even with a low level of expression (exerting lower metabolic burden onto the cells and making it more suitable for enzymatic cascading), the low $K_{\mathrm{M}}$-value, on the other hand, allows the enzyme to immediately react with a small amount of glucose and $\mathrm{NADP}^{+}$present in vivo. As GluDH-BA was successfully co-expressed along with the enzyme P450 BM3 in our previous study (Siriphongphaew et al. 2012), in this study, a whole-cell B. subtilis overexpressing GluDH-BA alone was evaluated as a cofactor regenerator in a coupling whole-cell system instead. Coupling wholecell system offers several advantages including process flexibility as well as an opportunity to supplement additional cofactor externally. The enzymes-of-interest can be expressed in their most appropriate hosts and the enzyme activity level required for optimal bioconversion can be adjusted easily by adjusting the amount of each whole-cell biocatalyst used. Moreover, as a whole-cell biocatalyst generally maintains its cytoplasmic $\mathrm{pH}$ near neutrality via several acid and alkaline $\mathrm{pH}$ homeostasis (Booth 1985; Padan et al. 2005; Baker-Austin and Dopson 2007), the intracellular enzyme (GluDH-BA in our case) is well protected from an extreme $\mathrm{pH}$ outside the cells. This allows for longer use period of the biocatalyst as well as higher process flexibility (i.e. wider range of possible reactions, ease of process control). Although B. subtilis BA has been proven as an effective cofactor regenerator for a coupling whole-cell system in this study, for practical applications, it should be investigated further on its ability to be recycled or stored as a frozen cell pellet.

\section{Authors' contributions}

PC and TP carried out the molecular cloning experiments and enzyme purification. NS and TP conducted the enzyme characterization studies. PP performed the protein structural analysis work. TP drafted the manuscript with ideas contributed by PP, KH and WP. All authors read and approved the final manuscript.

\section{Author details}

${ }^{1}$ Department of Biotechnology, Faculty of Science, Mahidol University, Bangkok 10400, Thailand. ${ }^{2}$ Department of Biotechnology, Graduate School of Engineering, Osaka University, Osaka, Japan. 


\section{Acknowledgements}

This work was supported by the Thailand Research Fund (TRF) under a Project Number MRG5580048 to TP with WP as her mentor. A gene encoding P450 BM3 F87V was kindly provided by Prof. Jun Ogawa from Division of Applied Life Sciences, Kyoto University, Japan.

\section{Competing interests}

The authors declare that they have no competing interests.

Received: 24 October 2015 Accepted: 27 October 2015

Published online: 04 November 2015

\section{References}

Adachi O, Matsushita K, Shinagawa E, Ameyama M (1980) Crystallization and characterization of NADP-dependent D-glucose dehydrogenase from Gluconobacter suboxydans. Agric Biol Chem 44:301-308

Baker-Austin C, Dopson M (2007) Life in acid: pH homeostasis in acidophiles. Trends Microbiol 15(4):165-171

Boontim N, Yoshimune K, Lumyong S, Moriguchi M (2004) Purification and characterization of D-glucose dehydrogenase from Bacillus thuringiensis M15. Ann Microbiol 54(4):481-492

Booth IR (1985) Regulation of cytoplasmic pH in bacteria. Microbiol Rev 49:359-378

Bradford MM (1976) A rapid and sensitive method for the quantification of microgram quantities of protein utilizing the principle of protein-dye binding. Anal Biochem 72:248-254

Cánovas M, Torroglosa T, Iborra JL (2005) Permeabilization of Escherichia coli cells in the biotransformation of trimethylammonium compounds into L-carnitine. Enzyme Microb Tech 37(3):300-308

Carius Y, Christian H, Faust A, Zander U, Klink BU, Kornberger P, Kohring GW, Giffhorn F, Scheidig AJ (2010) Structural insight into substrate differentiation of the sugar-metabolizing enzyme galactitoldehydrogenase from Rhodobacter sphaeroides D. J Biol Chem 285(26):20006-20014

de Wildeman SMA, Sonke T, Schoemaker HE, May O (2007) Biocatalytic reductions: from lab curiosity to "first choice". Accounts Chem Res 40:1260-1266

Ding HT, Du YQ, Liu DF, Li ZL, Chen XJ, Zhao YH (2011) Cloning and expression in E. coli of an organic solvent-tolerant and alkali-tolerant glucose 1-dehydrogenase from Lysinibacillus sphaericus G10. Biores Technol 102:1528-1536

Fujita Y, Ramaley R, Freese E (1977) Location and properties of glucose dehydrogenase in sporulating cells and spores of Bacillus subtilis. J Bacteriol 132:282-293

Giardina P, DeBasia MG, DeRosa M, Gambacort A, Buonocore V (1986) Glucose dehydrogenase from the thermoacidophilic archaebacterium Sulfolobus solfataricus. Biochem J 239:517-522

Hilt W, Pfleiderer G, Fortnagel P (1991) Glucose dehydrogenase from Bacillus subtilis expressed in Escherichia coli l: purification, characterization and comparison with glucose dehydrogenase from Bacillus megaterium. BBA Protein Struct M 1076(2):298-304

Idriss EE, Iglesias DJ, Talon M, Borriss R (2007) Tryptophan-dependent production of indole-3-acetic acid (IAA) affects level of plant growth promotion by Bacillus amyloliquefaciens FZB42. Mol Plant Microbe Interact 20(6):619-626

Laemmli UK (1970) Cleavage of structural proteins during the assembly of the head of bacteriophage T4. Nature 227(5259):680-685

Mitamura T, Urabe I, Okada H (1989) Enzymatic properties of isozymes and variants of glucose dehydrogenase from Bacillus megaterium. Eur J Biochem 186(1-2):389-393

Nagao T, Makino Y, Yamamoto K, Urabe I, Okada H (1989) Stability-increasing mutants of glucose dehydrogenase. FEBS Lett 253(1-2):113-116

Nagao T, Mitamura T, Wang XH, Negoro S, Yomo T, Urabe I, Okada H (1992) Cloning, nucleotide sequences, and enzymatic properties of glucosedehydrogenase isozymes from Bacillus megaterium IAM1030. J Bacteriol 174(15):5013-5020

Nishioka T, Yasutake Y, Nishiya Y, Tamura T (2012) Structure-guided mutagenesis for the improvement of substrate specificity of Bacillus megaterium glucose 1-dehydrogenase IV. FEBS J 279:3264-3275
Nishiya Y, Tamura N, Tamura T (2004) Analysis of bacterial glucose dehydrogenase homologs from thermoacidophilic archaeon Thermoplasma acidophilum: finding and characterization of aldohexose dehydrogenase. Biosci Biotechnol Biochem 68(12):2451-2456

Padan E, Bibi E, Ito M, Krulwich TA (2005) Alkaline $\mathrm{pH}$ homeostasis in bacteria: new insights. Biochim Biophy Acta 1717:67-88

Persson B, Kallberg Y, Bray JE, Bruford E, Dellaporta SL, Favia AD, Duarte RG, Jörnvall H, Kavanagh KL, Kedishvili N, Kisiela M, Maser E, Mindnich R, Orchard S, Penning TM, Thornton JM, Adamski J, Oppermann U (2009) The SDR (short-chain dehydrogenase/reductase and related enzymes) nomenclature initiative. Chem Biol Interact 178(1-3):94-98

Ramaley RF, Vasantha N (1983) Glycerol protection and purification of Bacillus subtilis glucose dehydrogenase. J Biol Chem 258(20):12558-12565

Rath A, Glibowicka M, Nadeau VG, Chen G, Deber CM (2009) Detergent binding explains anomalous SDS-PAGE migration of membrane proteins. PNAS 106(6):1760-1765

Reetz MT, Carballeira JD, Vogel A (2006) Iterative saturation mutagenesis on the basis of $\mathrm{B}$ factors as a strategy for increasing protein thermostability. Angew Chem Int Ed Engl 45:7745-7751

Richter N, Neumann M, Liese A, Wohlgemuth R, Weckbecker A, Eggert T, Hummel W (2010) Characterization of a whole-cell catalyst co-expressing glycerol dehydrogenase and glucose dehydrogenase and its application in the synthesis of L-glyceraldehyde. Biotechnol Bioeng 106(4):541-552

Rodriguez H, Fraga R (1999) Phosphate solubilizing bacteria and their role in plant growth promotion. Biotechnol Adv 17:319-339

Sambrook J, Russell DW (2001) Molecular cloning: a laboratory manual, 3rd edn. Cold Spring Harbor Laboratory Press, New York

Schewe H, Kaup BA, Schrader J (2008) Improvement of P450BM-3 whole-cell biocatalysis by integrating heterologous cofactor regeneration combining glucose facilitator and dehydrogenase in E. coli. Appl Microbiol Biotechnol 78:55-65

Siriphongphaew A, Pisnupong P, Wongkongkatep J, Inprakhon P, Vangnai AS, Honda K, Ohtake H, Kato J, Ogawa J, Shimizu S, Urlacher VB, Schmid RD, Pongtharangkul T (2012) Development of a whole-cell biocatalyst co-expressing P450 monooxygenase and glucose dehydrogenase for synthesis of epoxyhexane. Appl Microbiol Biotechnol 95:357-367

Stoll VS, Blanchard JS (1990) Buffers: principles and practice. Meth Enzmol 182:24-38

Vázquez-Figueroa E, Chaparro-Riggers J, Bommarius AS (2007) Development of a thermostable glucose dehydrogenase by a structure-guided consensus concept. ChemBioChem 8:2295-2301

Vázquez-Figueroa E, Yeh V, Broering JM, Chaparro-Riggers JF, Bommarius AS (2008) Thermostable variants constructed via the structure-guided consensus method also show increased stability in salts solutions and homogeneous aqueous-organic media. Protein Eng Des Sel 21:673-680

Wang Y, Li L, Ma C, Gao C, Tao F, Xu P (2013) Engineering of cofactor regeneration enhances (2S,3S)-2,3-butanediol production from diacetyl. Sci Rep $3: 2643$

Weckbecker A, Hummel W (2005) Glucose dehydrogenase for the regeneration of NADPH and NADH. In: Barredo JL (ed) Methods in Biotechnology, microbial enzymes and biotransformations, vol 17. Humana Press Inc, Totowa, pp 225-237

Xu Z, Jing K, Liu Y, Cen P (2007) High-level expression of recombinant glucose dehydrogenase and its application in NADPH regeneration. J Ind Microbiol Biotechnol 34(1):83-90

Yamamoto K, Nagao T, Makino Y, Urabe I, Okada H (1990) Characterization of mutant glucose dehydrogenase with increasing stability. Ann NY Acad Sci 613:362-365

Zhang W, O'Connor K, Wang DIC, Li Z (2009) Bioreduction with efficient recycling of NADPH by coupled permeabilized microorganisms. Appl Environ Microbiol 75(3):687-694

Zhang JD, Li AT, Yu HL, Imanaka T, Xu JH (2011) Synthesis of optically pure S-sulfoxide by Escherichia coli transformant cells coexpressing the P450 monooxygenase and glucose dehydrogenase genes. J Ind Microbiol Biotechnol 38(5):633-641

Zhu Y, Chen X, Chen T, Shi S, Zhao X (2006) Over-expression of glucose dehydrogenase improves cell growth and riboflavin production in Bacillus subtilis. Biotechnol Lett 28:1667-1672 